\title{
How the Implementation of a First-Year Experience Program Could Improve Student Satisfaction and Sense of Belonging at an Urban Mid-Sized College: A Qualitative Study Utilizing Students' Perceptions.
}

\section{Joshua Wilkin}

This study gathered information from first-, second-, and third-year on-campus students to better understand their perceptions of their college experiences and how the creation of a first-year experience program could improve student satisfaction and sense of belonging at an urban mid-sized college. The qualitative data in this study revealed the importance of utilizing students' perceptions to improve the college experience.

This particular college, along with 27 other institutions, administers a Student Opinions Survey (SOS), every three years, to collect information on students' satisfaction with their academic experiences, student support services, and campus resources and programs. This information is used in the strategic planning process, as well as in academic and administrative improvement efforts. In the most current Student Opinions Survey (2012), this college ranked in the bottom half of schools for all items measuring student satisfaction with various campus services. Additionally, only 59\% of students felt a sense of belonging to the campus.

Given this information, in its most current strategic plan, the college mentioned implementing a first-year experience program for students to improve student satisfaction and sense of belonging at the college. This qualitative study sought to gather information from first-, second-, and third-year on-campus students to better understand their perceptions of the college and how the creation of a first-year experience program could improve student satisfaction and sense of belonging.

\section{Literature Review}

While many studies have focused on the effectiveness of first-year experience

Joshua Wilkin (joshuawilkin@gmail.com) is the Associate Director for Campus Life at Bryant University 
programs, surprisingly, there have been fewer studies that focus on student perceptions of these programs. Schrader and Brown (2008) researched student perceptions of a first-year experience program at a large Northeastern university in 2002. Results indicated that students who voluntarily enrolled in a first-year experience program rate their knowledge of campus resources higher than those who did not choose to participate. One concern, however, is that self-selection of participants could be problematic because the participants' positive or negative experience in the program could bias the data.

Brinkworth, McCann, Matthews, and Nordström (2008) conducted a broad survey study of first-year expectations and experiences of teaching and learning from the perspective of students and teachers at the University of Adelaide, Australia, 6 months into their first year and again during their second year. Results revealed that students need peer support, self-motivation, and feedback and support from the university to help them develop and achieve greater success in college. Further research regarding student and teacher perceptions may help researchers and educators discover discrepancies in perceptions between students and faculty.

Meyer, Spencer, and French (2009) interviewed 52 college freshmen at a small liberal arts university in 2006. According to their study, almost all of the first-year students who were interviewed approached their first semester with the perception that the academic workload and classes were going to be challenging. However, through Meyer et al.'s study, many students felt their college experience would be more challenging than their expectations. While their study did not specifically discuss first-year experience programs, it does demonstrate that further qualitative research is needed to focus more on how students make meaning of their first-year experience. This is a clear gap in the literature in which responses could be used to alter-or when creating_-first-year experience programs.

\section{Method}

The first step in the research process was sending out an email to first-, second-, and third-year students who live on campus and are enrolled at the college. First-, second-, and third-year students (including transfer students) were selected if they had completed at least one semester at the college because they would have the most insight regarding how a first-year experience program could have better improved their first year as a student. Fourth-year students were omitted because many are likely close to completing their studies and may be focused on graduation.

The email participants received introduced the nature of the project and asked if they were interested in participating in a study to determine how the implementation of a first-year experience program could improve student satisfaction and sense of belonging at the college. If interested, a follow-up email was sent asking for background information of the individual (gender, name, age, major, and length of time at college). Each background profile was reviewed to 
ensure the sample contained first-, second-, and third-year students. I then used stratified random sampling by separating participants into two groups by gender and rank year and then randomly selected 30 participants (out of 60 who indicated interest), who then were broken down into 10 participants from year one, year two, and year three (approximately $90 \%$ female and $10 \%$ male to mirror the demographics of the college).

The data needed for this study came from a single 30-60 minute interview with 30 students. I also made sure to explain the background and purpose of a first-year experience program to provide context for participants.

\section{TABLE 1}

\section{Semi-Structured Interview Questions}

1. What types of academic support are available for first-year students at the college?

2. What types of social support are available for first-year students at the college?

3. What are your perceptions regarding the creation of a first-year experience program at the college?

4. What components would you like to see included in a first-year experience program at the college?

5. How should this program address student development skills and issues at the college?

6. What are some of the particular challenges that students at this college face in their first year, and how could a first-year experience program lessen these challenges?

7. If you were a first-year student, what would you need in this type of program to feel both challenged and supported?

8. What type of outcomes do you think this program will have for the campus and for its students?

\section{Results}

Out of 30 participants, 29 indicated that the implementation of a first-year experience program would address the gaps in student satisfaction and sense of belonging at the college. Participants felt this program should continue throughout the year and provide increased programmatic opportunities for students to engage socially and academically. 


\section{Discussion}

The key themes that emerged from this study revolved around interpersonal relationships, communicative support, and opportunities provided by the college.

As past research has indicated, a first-year experience program gives students the opportunity to have a successful transition to their new college or university surroundings (Tsui \& Gao, 2007; Woosley \& Miller, 2009). Additionally, "Extended first-year experience programs provide the opportunity for depth and breadth in areas that are critical to student success" (Habley, Bloom, \& Robbins, 2012). A firstyear participant shared, "I think a first-year experience program would be actually helpful — a required course that would be for first-year students, like the building blocks of how to adjust to living in the city, what to expect, what courses, and how you need to handle those."

Participants felt a course over the semester or year would be ideal. Many of the participants indicated that a first-year experience program would need to address time management, financial management, social adjustment, adaptability to difficult situations, and how to connect to support services from the college. These participants also felt professors could offer innovative workshops or discussion groups throughout the year to give students further opportunities to develop.

Participants wanted a first-year experience to increase social interactions. The majority of the complaints from the participants in this study was the fact that the college does not provide enough social support and programs for students. Participants mentioned it was very difficult to make friends at the college, and this program should provide more opportunities so students are able to meet and mingle. A third-year participant shared, "I think it could really, really help, actually. The more you know, the more skills you have to do well here and make it feel like your home, the more you're going to feel like it really is a place that you belong. Again, you'll be able to meet so many other different people and make more friends and stuff, which will really, really help."

Lastly, participants felt it would be helpful to have a mentorship program or buddy system where first-year students could meet with an upperclassman in their major and ask questions pertaining to their chosen field of study or other aspects related to the college. This information is supported by findings from Rode (2002) and Astin (1965), which indicated that peer mentorship is critical for student satisfaction and success.

\section{Limitations}

This study sought to answer why students were dissatisfied with campus services and lacked a sense of belonging, as indicated on the Student Opinions Survey. Therefore, this study is very specific to this institution, and findings of the study are not generalizable to other institutions. However, qualitative data concerning students' perceptions of their first-year experience could be used to improve the college experience at other institutions. 


\section{Recommendations}

Student affairs administrators should explore what students would like to see in a first-year experience program. A third-year participant shared, "If they specifically go out and see what everyone needs, why people don't feel like they belong, why they feel like they don't have support, then that way, they'll be able to cater more to the needs of students." While it is important for administrators to provide their own input, they sometimes fail to recognize that students can provide valuable suggestions and proper insight into what services they need in order to improve student satisfaction and sense of belonging at college.

\section{References}

Astin, A. (1965). Who goes where to college? Chicago, IL: Science Research Associates.

Brinkworth, R., McCann, B., Matthews, C., \& Nordström, K. (2009). First year expectations and experiences: Student and teacher perspectives. Higher Education, 58(2), 157-173. doi:10.1007/s10734-008-9188-3

Habley, W., Bloom, J., \& Robbins, S. (2012). Increasing persistence: Research-based strategies for college student success. San Francisco, CA: Jossey-Bass.

Meyer, M., Spencer, M., \& French, T. (2009). The identity of a "college student": Perceptions of college academics and academic rigor among first-year students. College Student Journal, 43(4), 1070-1080.

Rode, D. (2002). Enhancing and extended orientation courses through the use of peer instructors. The Journal of College Orientation and Transition, 4(1), 50-54.

Schrader, G. P., \& Brown, W. S. (2008). Evaluating the first year experience: Students' knowledge, attitudes, and behaviors. Journal of Advanced Academics, 19(2), 310-347.

Tsui, L., \& Gao, E. (2006). The efficacy of seminar courses. Journal of College Student Retention, 8(2), 149-170.

Woolsey, A. S., \& Miller, L. A. (2009). Integration and institutional commitment as predictors of college student transition: Are third week indicators significant? College Student Journal, 43(4), 1260-1272. 